\title{
TATA KELOLA PUBLIK DAN KINERJA KEUANGAN PEMERINTAH DAERAH DI INDONESIA
}

\author{
Handoko A Hasthoro \\ Fakultas Ekonomi, Universitas Janabadra Yogyakarta \\ handoko_arwi@janabadra.ac.id \\ Sunardi \\ Fakultas Ekonomi, Universitas Janabadra Yogyakarta
}

\begin{abstract}
The aims of this study is to examine the effect of public governance implementation on financial performance of Indonesian local governments. Public governance implementation was measured by local government's transparency, accountability, legal culture, and community participation. Fifty local governments surveyed by Tansparency International Indonesia in 2010 used as a sample. Results from multiple regression analysis show that legal culture which is proxied by corruption perception index, and community participation proxied by number of election voters had positive significant influence in Indonesian local governments financial performance. The result imply that law enforcement and fair election foster public trust to pay taxes that increasing genuine income.
\end{abstract}

Keywords: public governance, local government, financial performance, public sector accounting.

\begin{abstract}
ABSTRAK
Tujuan penelitian ini adalah untuk menguji pengaruh penerapan tata kelola publik terhadap kinerja keuangan pemerintah daerah di Indonesia. Pelaksanaan pemerintahan umum diukur dengan menggunakan transparansi pemerintah daerah, akuntabilitas pemerintah daerah, budaya hukum, dan partisipasi masyarakat. Sejumlah lima puluh pemerintah daerah yang disurvei oleh Tansparency International Indonesia pada tahun 2010 digunakan sebagai sampel. Hasil dari analisis regresi berganda menunjukkan bahwa budaya hukum yang ditunjukkan oleh indeks persepsi korupsi, dan partisipasi masyarakat yang diwakili oleh jumlah pemilih pemilu memiliki pengaruh signifikan positif pada kinerja keuangan pemerintah daerah di Indonesia. Hasil penelitian menunjukkan bahwa penegakan hukum dan pemilu yang adil mendorong kepercayaan masyarakat untuk membayar pajak yang meningkatkan pendapatan asli.
\end{abstract}

Kata kunci: pemerintahan umum, pemerintah daerah, kinerja keuangan, akuntansi sektor publik 


\section{PENDAHULUAN}

Tuntutan adanya transparansi dan akuntabilitas publik (public accountability) pada era reformasi membawa dampak terhadap dalam proses pengembangan manajemen pemerintahan di Indonesia. Transparansi dan akuntabilitas publik merupakan dua sisi yang tidak terpisahkan sebagai bagian dari prinsip-prinsip tata kelola yang baik (good governance). Implikasinya, kini keduanya menjadi kajian yang marak dan interchangable, penerapannya pada pola perencanaan, pelaksanaan dan pertanggung jawaban keuangan daerah yang partisipatif sebagai suatu konsekuensi logis. Isu seputar transparansi dan akuntabilitas tidak terlepas dari maraknya penyalahgunaan wewenang dan penyelewengan dana oleh oknum pegawai maupun pejabat di pemerintahan. Transparansi dan akuntabilitas membutuhkan media agar bisa dikomunikasikan ke masyarakat secara lebih baik dan cepat (Bertot, Jaeger, \& Grimes 2012).

Perubahan konstelasi politik dan proses demokratisasi akibat gerakan reformasi telah menuntut pengelolaan pemerintahan untuk lebih baik (good government governance atau good public governance). Tata kelola publik memfokuskan bagaimana kebijakan publik diimplementasikan dan pelayanan publik dilakukan Osborne (2010), yang menyangkut perilaku dan kontribusi pada kinerja pemerintahan (Hill \& Lynn 2004). Transparansi dalam proses manajemen keuangan daerah di era kebijakan otonomi, membutuhkan pola akuntabilitas publik melalui pembangunan sistem akuntansi pemerintahan memberikan peluang terhadap peningkatan penyediaan informasi yang handal dan akurat serta berorientasi pada peningkatan tolok ukur kinerja dalam memberikan pelayanan publik yang maksimal, dan merupakan proses pertanggungjawaban (stewardship and accountability process), manajerial dan unsur pengendalian manajemen di pemerintah daerah.

Implementasi kebijakan publik dan proses pelayanan kepada publik telah melalui tahapan rejim, yaitu: administrasi publik sejak awal abad ke-19 hingga akhir tahun 1970an, kemudian era manajemen publik baru (New Public Management/NPM) dari awal 1980-an hingga awal abad ke-21 dan era tata kelola publik baru (New Public Governance/NPG) hingga saat ini (Osborne 2010). Menurut Bovaird dan Löffler (2003), administrasi publik mempelajari tentang kerja pegawai pemerintah dan pelayan masyarakat termasuk hubungannya dengan politisi yang terlibat dalam proses legislasi dan penetuan kebijakan publik. NPM membahas tentang manajemen anggaran, budaya kontrak, semangat wirausaha dan akuntabilitas untuk kinerja. Pembahasan tentang NPG adalah bagaimana interaksi para stakeholder satu sama lainnya dalam mengupayakan manfaat dari kebijakan publik.

Di Indonesia, good public governance (GPG) diperlukan dalam rangka mencapai tujuan nasional yaitu melindungi segenap Bangsa Indonesia dan seluruh tumpah darah Indonesia dan untuk memajukan kesejahteraan umum, mencerdaskan kehidupan bangsa, serta ikut memelihara ketertiban dunia berlandaskan kedaulatan negara, perdamaian abadi dan keadilan sosial (Komite Nasional Kebijakan Governance 2010). Untuk 
mencapai tujuan tersebut harus diwujudkan negara berdaya-saing sehat dan tinggi yang mampu menciptakan nilai tambah secara berkesinambungan melalui pengelolaan sumber daya secara bertanggung jawab sehingga terbangun kredibilitas negara baik secara nasional maupun dalam pergaulan internasional.

KNKG membagi good governance menjadi dua, yaitu good corporate governance (GCG) dan good public governance. Pedoman pelaksanaan di Indonesia untuk GCG telah dikeluarkan pada tahun 2006 dan untuk GPG tahun 2010. GPG memiliki pengaruh yang besar terhadap terwujudnya good governance secara menyeluruh, baik dalam rangka penyelenggaraan negara itu sendiri, maupun dalam berbagai aspek kehidupan masyarakat, termasuk penerapan good corporate governance oleh dunia usaha. Di pihak lain dunia usaha dan masyarakat juga berkepentingan dan memiliki peran dalam mewujudkan GPG. Oleh karena itu, dalam rangka menciptakan situasi kondusif untuk melaksanakan GPG diperlukan tiga pilar, yaitu negara, dunia usaha dan masyarakat.

Kinerja keuangan pemerintah daerah pada era otonomi daerah yang belum baik menjadi permasalahan yang harus segera diselesaikan. Kinerja bahkan cenderung menurun di era otonomi dibanding sebelum otonomi (Hariyadi 2002; Azhar 2010). Penelitian oleh Akbar, Pilcher, dan Perrin (2012) menunjukkan bahwa pemerintah daerah berupaya mencapai kinerja lebih untuk memenuhi peraturan daripada menciptakan efisiensi dan efektifitas dalam program dan kebijakan. Permasalahan governance pada pemerintah daerah di Indonesia belum menunjukan ke arah yang lebih baik. Hal ini dibuktikan dengan masih banyaknya kasus korupsi dan upaya-upaya untuk mereformasi birokrasi. Menarik untuk diteliti lebih lanjut apakah ada permasalahan governance dalam pemerintahan dalam pencapian kinerja keuangan.

Kinerja keuangan pemerintah daerah menjadi sorotan masyarakat karena tuntutan akan transparansi dan akuntabilitas. Penelitian ini menguji secara empiris penerapan prinsip-prinsip dalam good public governance $(G P G)$ terhadap kinerja keuangan pemerintah daerah di Indonesia. Prinsip-prinsip dalam GPG meliputi demokrasi, transparansi, akuntabilitas, budaya hukum dan kewajaran dan kesetaraan. Penelitian oleh Akbar et al. (2012) menemukan bahwa pencapaian kinerja oleh pemerintah daerah hanya untuk memenuhi peraturan bukan penekanan faktor internal yang sungguh-sungguh dalam mencapai kinerja. Hal lain yang dilakukan oleh Azhar (2010) adalah membandingkan kinerja pemerintah daerah sebelum dan sesudah otonomi daerah dengan derajat desentralisasi fiskal sebagai ukurannya. Sumarjo (2010) dan Mustikarani dan Fitriasari (2012) menggunakan karakteristik pemerintah daerah sebagai prediktor bagi kinerja bukan upaya-upaya tertentu dari pemerintah daerah tersebut.

Penelitian ini menggunakan upaya-upaya oleh internal pemerintah daerah dalam usaha mencapai target kinerja yang telah ditetapkan. Prinsip-prinsip public governance digunakan sebagai proksi untuk upaya-upaya oleh internal pemerintah daerah yang meliputi demokrasi (partisipasi), transparansi, akuntabilitas dan budaya hokum (Komite 
Nasional Kebijakan Governance 2010). Model penelitian governance yang diterapkan di penelitian bisnis, yaitu corporate governance, untuk menguji pengaruhnya terhadap kinerja coba diadopsi dalam penelitian ini. Topik penelitian mengenai pubic governance yang dihubungkan dengan kinerja pemerintah di Indonesia belum pernah dilakukan. Hal ini penting untuk memulainya dan dilakukan tindak lanjut agar penelitian tentang public governance bisa semarak sebagaimana penelitian tentang corporate governance.

Sebagai referensi bagi upaya-upaya peningkatan kinerja keuangan dan mengidentifikasi faktor-faktor yang menjadi penyebabnya sebagaimana tuntutan para pemangku kepentingan dalam mewujudkan tata kelola pemerintahan yang baik (good government/public governance). Hasil penelitian ini juga bermanfaat untuk memberi referensi penelitian berikutnya yang mengkaji akuntansi sektor publik bidang pemerintahan. Pengembangan model penelitian dan eksplorasi variabel dapat dikembangkan seiring dengan kompleksnya permasalahan yang dihadapi pemerintah dalam mewujudkan good government/public governance.

\section{KAJIAN PUSTAKA DAN PERUMUSAN HIPOTESIS}

Kinerja adalah gambaran mengenai tingkat pencapaian pelaksanaan suatu kegiatan atau program dan kebijakan dalam mewujudkan sasaran, tujuan, misi dan visi organisasi yang tertuang dalam perencanaan stratejik suatu organisasi (Bastian 2010). Kinerja keuangan mempunyai arti penentuan ukuran-ukuran tertentu yang dapat mengukur keberhasilan suatu organisasi dalam memperoleh pendapatan. Dengan kata lain, kinerja keuangan adalah suatu ukuran kinerja yang menggunakan indikator keuangan. Analisis kinerja keuangan pada dasarnya dilakukan untuk menilai kinerja di masa lalu dengan melakukan berbagai analisis sehingga diperoleh posisi keuangan yang mewakili realitas entitas dan potensi-potensi kinerja yang akan berlanjut. Istilah kinerja digunakan untuk menyebut prestasi atau tingkat keberhasilan individu maupun kelompok. Kinerja bisa diketahui hanya karena individu atau kelompok tersebut mempunyai kriteria keberhasilan yang telah ditetapkan. Kriteria keberhasilan ini berupa tujuan-tujuan atau target-target tertentu yang hendak dicapai sehingga tanpa ada tujuan atau target kinerja seseorang atau organisasi tidak dapat diketahui karena tidak ada tolok ukurnya.

Untuk dapat mengetahui kinerja dengan baik maka dibutuhkan sebuah sistem yang dinamakan pengukuran kinerja. Pengukuran kinerja (performance measurement) adalah suatu proses penilaian kemajuan pekerjaan terhadap tujuan dan sasaran yang telah ditentukan sebelumnya, termasuk informasi atas efesiensi penggunaan sumber daya dalam menghasilkan barang dan jasa, kualitas barang dan jasa (seberapa baik barang dan jasa diserahkan pada pelanggan dan sampai seberapa jauh pelanggan terpuaskan), hasil kegiatan dibandingkan dengan maksud yang diinginkan dan efektivitas tindakan dalam mencapai tujuan (Verbeeten 2008). Menurut Arja Sadjiarto (2000), ada dua elemen faktor yang memengaruhi kinerja organisasi pemerintah yaitu elemen yang diluar kontrol 
pemerintah (demografi, lingkungan dan lainnya) dan elemen yang dapat dikontrol pemerintah (alokasi dana, penentuan jumlah personalia dan lainnya).

Peningkatan kinerja bisa dipicu karena peningkatan akuntabilitas organisasi. Penggunaan akuntansi akrual dipercaya akan menciptakan akuntabilitas yang lebih tinggi atas aktivitas pada organisasi sektor publik yang pada akhirnya bertujuan meningkatkan akuntabilitas pemerintahan serta memperbaiki kualitas pengambilan keputusan dalam lingkungan pemerintahan. Beberapa studi membuktikan bahwa defisiensi dalam sistem akuntansi merupakan kelemahan penting dalam manajemen sektor publik terutama di negara-negara berkembang (Marwata \& Alam 2006; Wyk 2007; Adhikari \& Mellemvik 2011). Dalam hal kinerja, relatif sedikit yang bisa diketahui tentang pengukuran kinerja sektor publik dalam konteks negera sedang berkembang (Mimba, Helden, \& Tillema 2007).

\section{Public Governance dan Kinerja Keuangan}

Prinsip-prinsip dalam public governance dewasa ini telah banyak dikaji dan dibahas dalam berbagai kesempatan. Pemerintah daerah memang dituntut untuk memaksimalkan sumberdaya yang dimiliki untuk mencapai target yang telah ditetapkan. Peningkatan kesadaran masyarakat terhadap penyelenggaraan administrasi publik memicu timbulnya gejolak yang berakar dari ketidakpastian. Tuntutan yang semakin tinggi diajukan terhadap pertanggungjawaban yang diberi oleh penyelenggara negara atas kepercayaan yang diamanatkan kepada mereka. Kondisi ini menyababkan instansi pemerintah kini lebih banyak mendapat sorotan, karena masyarakat mulai mempertanyakan manfaat yang mereka peroleh atas pelayanan instansi pemerintah (Mardiasmo 2009).

Dalam era reformasi sektor publik, pemerintah diharapkan bisa melaporkan hasil dari program yang telah dijalankan untuk dapat dinilai apakah pemerintah berkerja secara ekonomis, efektif dan efisien. Kinerja keuangan pemerintah menjadi fokus perhatian baik oleh pejabat pemerintah maupun stakeholder lainnya. Hal tersebut dikarenakan isu-isu seputar pengelolaan keuangan pemerintah selalu menarik untuk disorot untuk berbagai kepentingan, terutama isu seputar korupsi. Solusi keuangan pemerintah daerah masih mengandalkan pemberian dana dari pemerintah pusat, dan ini menjadi sumber ketergantungan pemerintah daerah (Patrick 2007).

Pemerintah Republik Indonesia mengeluarkan Undang-Undang No 32 Tahun 2004 tentang Pemerintah Daerah dan Undang-Undang No 33 Tahun 2004 tentang Perimbangan Keuangan untuk mengatasi ketergantungan pemerintah daerah terhadap pusat dengan mekanisme otonomi daerah. Pemberian otonomi daerah diharapkan dapat meningkatkan efisiensi, efektivitas dan akuntabilitas pengelolaan keuangan pemerintah daerah di Indonesia. Dengan otonomi, daerah dituntut untuk mencari alternatif sumber pendanaan pembangunan dan menggunakan dana publik sesuai dengan peraturan hukum, prioritas dan aspirasi masyarakat. 
Kondisi seperti ini membuat peranan investasi swasta dan perusahaan milik daerah sangat diharapkan sebagai pemacu utama pertumbuhan dan pembangunan ekonomi daerah, sehingga pemerintah daerah dituntut untuk menyiapkan infrastruktur yang memadai. Investasi yang masuk akan berdampak pada pertumbuhan ekonomi daerah. Pemerintah daerah juga didorong untuk lebih berkreasi dan berinovasi dalam menggali potensi daerah untuk meningkatkan pendapatan.

\section{Pengembangan Hipotesis}

\section{Hubungan Transparansi dengan Kinerja Keuangan Daerah}

Transparansi adalah memberikan informasi yang terbuka dan jujur kepada masyarakat berdasarkan pertimbangan bahwa masyarakat memiliki hak untuk mengetahui secara terbuka dan menyeluruh atas pertanggungjawaban pemerintah dalam pengelolaan sumber daya yang dipercayakan kepadanya dan ketaatannya pada peraturan perundang- undangan (Komite Nasional Kebijakan Governance 2010). Perkembangan tehnologi informasi juga merambah ke sektor pemerintahan. Pemerintahan yang dilakukan dengan media tehnologi informasi ini sering disebut sebagai e-government. Transparansi pemerintah bisa dilakukan melalui media $e$ government dengan membuat sebuah situs. Situs (website) menjadikan pemerintah daerah mudah berkomunikasi dengan masyarakat dan lingkungan eksternal. Sebuah situs merupakan alat komunikasi yang unggul yang menggambarkan budaya dan daya tanggap pemerintah daerah kepada masyarakat (Deakins et al., 2010; Patrick 2007). Penelitian oleh Patrick (2007) membuktikan bahwa kualitas situs berpengaruh terhadap inovasi organisasi pemerintah. Inovasi organisasi diperlukan untuk mencapai target kinerja yang telah ditetapkan. Pada penelitian ini transparansi diproksi dengan e-government. Indeks kualitas e-government, yang merupakan hasil evaluasi oleh lembaga independen atas pelaksanaan e-government pada waktu tertentu. Indeks berkisar antara 0 sampai dengan 1. Angka indeks yang mendekati 1 bisa dikatakan kualitas e-government semakin bagus. Berdasarkan argumentasi dan hasil riset terdahulu, dapat dirumuskan hipotesis sebagai berikut.

H1: Transparansi berpengaruh positif terhadap kinerja keuangan daerah.

\section{Hubungan Akuntabilitas dengan Kinerja Keuangan Daerah}

Akuntabilitas adalah mempertanggungjawabkan pengelolaan sumber daya serta pelaksanaan kebijakan yang dipercayakan kepada entitas pelaporan dalam mencapai tujuan yang telah ditetapkan secara periodic (Komite Nasional Kebijakan Governance 2010). Akuntabilitas diwujudkan dalam sejauh mana upaya pemerintah daerah dalam mempertanggungjawabkan program kerja dan kebijakan yang telah dijalankan. Dalam hal kinerja keuangan, peran lembaga independen seperti Badan Pemeriksa Keuangan (BPK) sangat penting untuk menilai akuntabilitas suatu pemerintah daerah. Pemerintah daerah yang mendapat penilaian baik akan menumbuhkan kepercayaan dari masyarakat dan termotivasi untuk meningkatkan kinerjanya. Akuntabilitas lebih diarahkan untuk meningkatkan kinerja daripada memenuhi kebijakan tertentu dalam peraturan 
perundangan (Forbes, Hill, \& Lynn, Jr. 2006). Pada penelitian ini akuntabilitas diproksi dengan opini audit BPK atas laporan keuangan pemerintah daerah. Opini audit merupakan variabel dummy, dimana skor 1 untuk opini wajar tanpa pengecualian (unqualified) dan skor 0 untuk opini lainnya.

H2: Akuntabilitas berpengaruh positif terhadap kinerja keuangan daerah.

\section{Budaya Hukum}

Budaya hukum merupakan orientasi pemerintahan yang mengandung unsur penegakan hukum secara tegas tanpa pandang bulu dan ketaatan terhadap hukum oleh masyarakat berdasar kesadaran (Komite Nasional Kebijakan Governance 2010). Budaya hukum mengandung unsur penegakan hukum secara tegas tanpa pandang bulu dan ketaatan pada hukum oleh masyarakat berdasarkan kesadaran. Menurut Mardiasmo (2009) budaya hukum menunjukkan orientasi pemerintah dalam menjalankan program dan kebijakan. Mereka berpendapat bahwa salah satu budaya hukum itu adalah dengan pemberantasan korupsi di pemerintahan. Hal ini memperkuat temuan Tanzi \& Davoodi (1997) bahwa korupsi bisa menurunkan pendapatan pemerintah (kinerja keuangan). Budaya hukum yang baik akan meningkatkan kepatuhan pegawai dan pejabat di pemerintahan terhadap aturan perundang-undangan. Kepatuhan inilah yang bisa memotivasi pemerintah untuk melakukan upaya-upaya bagi peningkatan kinerja yang lebih baik. Pada penelitian ini budaya hukum diproksi dengan indeks persepsi korupsi yang disusun oleh Transparency International Indonesia pada tahun 2010. Indeks berkisar antara 1 sampai dengan 10, dimana 1 adalah korup dan 10 adalah bersih. Dengan mencermati argumentasi dan hasil riset terdahulu, maka hipotesis tiga dirumuskan sebagai berikut.

H3: Budaya hukum berpengaruh positif terhadap kinerja keuangan daerah.

\section{Hubungan Partisipasi dengan Kinerja Keuangan Daerah}

Partisipasi adalah peran serta masyarakat dalam proses penyelenggaraan dan penyusunan kebijakan publik. Partisipasi merupakan salah satu unsur pokok dalam demokrasi yang mana aspirasi dan keikutsertaan dalam pemilihan umum menjadi bukti peran serta masyarakat tersebut (Komite Nasional Kebijakan Governance 2010). Partisipasi masyarakat merupakan unsur penting dalam demokrasi. Keterlibatan tersebut mampu mendorong pelaksanaan good governance di organisasi pemerintahan, karena masyarakat sebagai stakeholder penting dalam penyelenggaraan negara atau pemerintahan. Coryanata (2007) memberi bukti empiris bahwa partisipasi memengaruhi hubungan pengetahuan anggota dewan dengan pengawasan oleh anggota dewan. Pengawasan yang baik oleh anggota dewan diharapkan dapat memberi tekanan pada pemerintah agar berkinerja dengan lebih baik. Partisipasi dapat meningkatkan kepercayaan dan kepatuhan masyarakat terhadap pemerintah sehingga pemerintah termotivasi dalam meningkatkan kinerjanya.

H4: Partisipasi berpengaruh positif terhadap kinerja keuangan daerah. 


\section{Model Penelitian}

Model penelitian disajikan pada gambar 1 berikut.

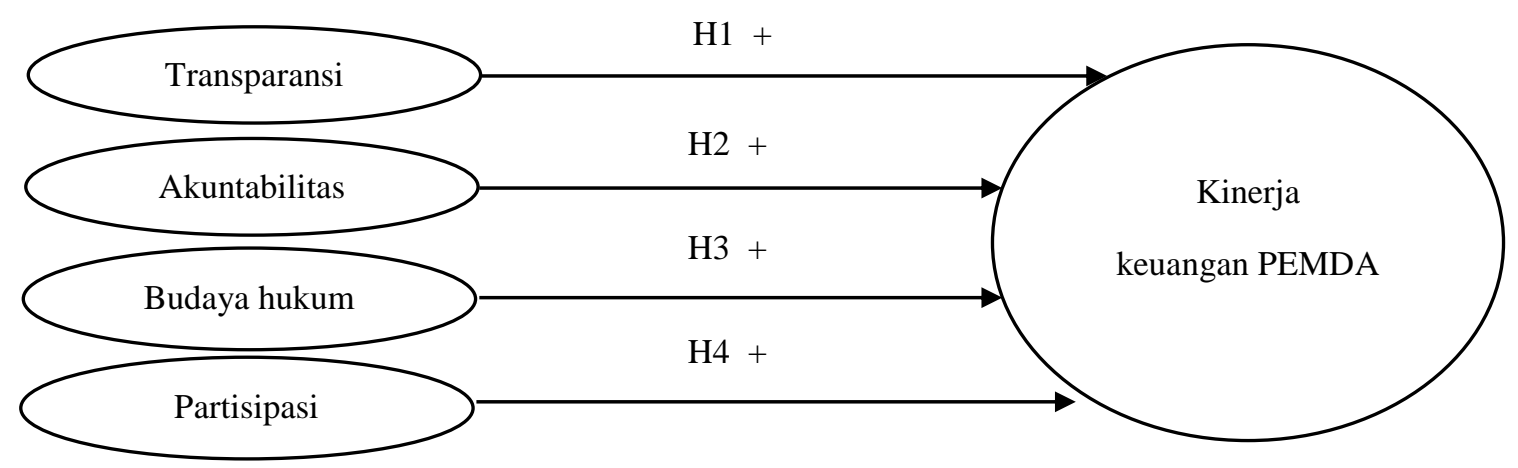

Gambar 1

Model Penelitian

\section{METODA PENELITIAN}

\section{Sampel dan Data Penelitian}

Populasi dalam penelitian ini adalah pemerintah daerah tingkat II seluruh Indonesia. Sampel yang digunakan adalah pemerintah daerah yang masuk dalam survei oleh Transparency International Indonesia tahun 2010, indeks e-government oleh Universitas Gunadarma tahun 2010 dan laporan keuangannya tahun 2010 telah disampaikan ke Direktorat Jenderal Perimbangan Keuangan Kementerian Keuangan Republik Indonesia.

\section{Sumber Data}

Sumber data diperoleh dari laman Transparency International Indonesia, laman Universitas Gunadarma, laman Dirjen Perimbangan Keuangan Kementerian Keuangan, laman masing-masing PEMDA, laman Komisi Pemilihan Umum dan laman BPK.

\section{Pengujian Hipotesis}

Pengujian hipotesis dilakukan dengan Uji Multiple Regression dengan alpha 5 persen dan alternatif 10 persen. Model regresi liner berganda dalam penelitian ditunjukan oleh persamaan berikut (Gujarati dan Porter, 2010):

$Y=\beta_{0}+\beta_{1} X_{1}+\beta_{2} X_{2}+\beta_{3} X_{3}+\beta_{4} X_{4}+\beta_{5} X_{5}+\varepsilon$ . .1

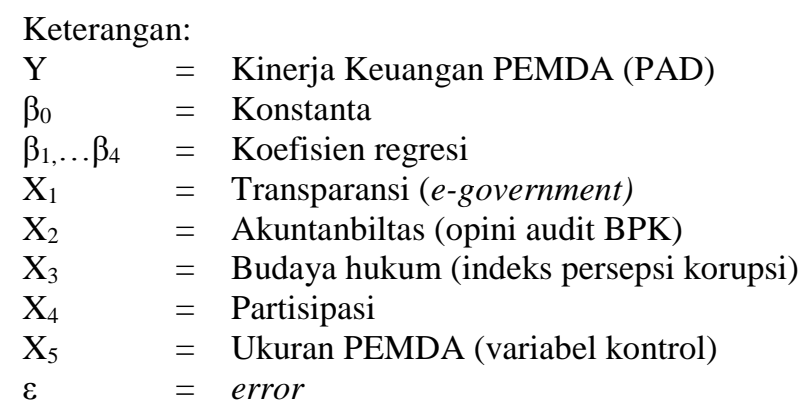




\section{ANALISIS DAN PEMBAHASAN}

\section{Deskripsi Objek Penelitian}

Objek penelitian ini adalah pemerintah daerah yang terseleksi dalam pemilihan sampel yang terdiri dari pemerintah kota sebanyak 46, pemerintah kabupaten sebanyak 4 , dan pemerintah provinsi ada 1 . Total sampel yang digunakan adalah 50 pemerintah daerah.

\section{Statistik Deskriptif}

Tahap ini menyajikan statistik deskriptif untuk variabel dependen (terikat) dan variabel independen (bebas). Statistik deskriptif menggambarkan data numerik dan menyajikan informasi mengenai keseluruhan data dari variabel yang digunakan (Patrick 2007). Statistik deskriptif meliputi statistik dasar seperti mean, minimum, maximum, dan standar deviasi. Pembahasan dimulai dari variabel dependen terlebih dahulu, yaitu kinerja keuangan daerah. Variabel independen dibahas secara berturut-turut mulai dari ukuran transparansi, akuntabilitas, budaya hukum, dan partisipasi. Tabel statistik deskriptif disajikan berikut ini:

Tabel 1

Statistik Deskriptif

\begin{tabular}{lrrr}
\hline & Rata-rata & Std Deviasi & N \\
\hline Y & 4,9306 & 0,51871 & 50 \\
X1 Transparasi & 0,2360 & 0,20871 & 50 \\
X2 Akuntabilitas & 0,12 & 0,328 & 50 \\
X3 Budaya hukum & 4,9304 & 0,66505 & 50 \\
X4 Partisipasi & 5,7344 & 0,39450 & 50 \\
X5 Ukuran Pemda(kontrol) & 12,3968 & 0,48619 & 50 \\
\hline
\end{tabular}

Otonomi daerah dimaksudkan agar pemerintah daerah dapat mengurangi ketergantungan dan meningkatkan kemandirian terhadap pemerintah pusat. Penelitian ini menggunakan PAD sebagai proksi untuk kinerja keuangan daerah. Ukuran yang digunakan adalah jumlah PAD dalam rupiah dan untuk kepentingan analisis digunakan log. Statistik deskriptif menunjukkan, dengan sampel sebanyak 50, rerata (mean) kinerja keuangan pemerintah daerah adalah 4,93 yang berarti tingkat PAD yang diperoleh masih rendah dan tingkat ketergantungan dengan pemerintah pusat masih tinggi. Hasil penelitian Azhar (2010) bahkan menunjukkan kinerja keuangan daerah di kabupaten/kota se-Aceh dan Sumatera Utara dalam bentuk desentralisasi fiskal cenderung menurun setelah pelaksanaan otonomi daerah.

E-Government adalah upaya pemerintah melakukan komunikasi dengan masyarakat melalui tehnologi dalam rangka meningkatkan akuntabilitas dan transparansi (Deakins et al., 2010). Rerata Indeks e-government 50 pemerintah daerah adalah 0,23. Angka tersebut masih jauh dari memadai dan menunjukkan implementasi e-government belum baik. Pemerintah daerah perlu mengalokasikan dana yang lebih besar lagi untuk implementasi e-government dan mempunyai kemauan politik yang lebih tinggi dalam upaya meningkatkan transparansi dan akuntabilitas pemerintahan. 
Akuntabilitas pemerintah daerah bisa dilihat sejauh mana kualitas laporan keuangan yang disusun. Opini audit oleh BPK menunjukan kualitas laporan keuangan yang dimaksud. Rerata opini audit 50 pemerintah daerah adalah 0,12 yang berarti kecenderungan opini mendekati tidak wajar atau belum unqualifed, laporan keuangan belum disusun dan disajikan dengan baik berdasar standar yang ada.

Penegakan hukum bisa dicapai dengan mewujudkan ketiadaan korupsi (absence of corruption). Korupsi menyebabkan permasalahan dalam pemerintahan baik secara ekonomik maupun politik. Rerata indeks persepsi korupsi 50 pemerintah daerah adalah 4,93. Rerata indeks menunjukan bahwa tingkat korupsi di pemerintahan daerah cukup tinggi. Kondisi ini sangat mengkhawatirkan karena semangat otonomi dan good governance yang diharapkan akan membawa pemerintahan ke arah yang lebih baik menjadi terkendala. Strategi pencegahan dan pemberantasan korupsi perlu ditingkatkan agar pemerintahan berjalan dengan baik dan masyarakat lebih sejahtera. Pencegahan bisa dilakukan dengan meningkatkan standar akuntansi dan auditing (Malagueño et al., 2010), atau dengan cara melakukan reformasi birokrasi (Mistry 2012).

Partisipasi masyarakat mendorong proses demokratisasi menjadi lebih maju. Partisipasi akan memberi tekanan tersendiri bagi pemerintah untuk bekerja secara serius dan sungguh untuk meningkatkan kinerja. Rerata angka partisipasi masyarakat di 50 pemerintah daerah adalah 5,73. Angka itu bisa dikatakan belum optimal karena masih ada kelompok-kelompok yang belum menyadari pentingnya partisipasi masyakarat dalam proses pemerintahan.

\section{Pengujian Hipotesis}

Pengujian hipotesis dilakukan menggunakan metoda regresi linier berganda. Tujuan pengujian hipotesis untuk membuktikan secara empiris pengaruh variabel independen terhadap variabel dependen. Hasil pengujian menggunakan regresi linier berganda.

Tabel 2

Hasil Regresi Linier Berganda

\begin{tabular}{lrrrr}
\hline \multicolumn{1}{c}{ Variabel } & Prediksi Arah & Koefisien & T & \multicolumn{1}{c}{ Sig. } \\
\hline (Constant) & + & 6,497 & $-7,630$ & 0,000 \\
Transparansi (Egov) & + & 0,099 & 0,690 & 0,494 \\
Akuntabilitas (Opau) & + & 0,006 & 0,061 & 0,951 \\
Budaya hukum (Bhuk) & + & 0,076 & 1,682 & $0,100 * *$ \\
Partisipasi (Part) & + & 0,473 & 4,005 & $0,000 *$ \\
Ukuran PEMDA (Size) & & 0,671 & 6,973 & 0,000 \\
$R$ Square & & 0,868 & & \\
Adjusted R-Square & & 0,853 & & \\
F & & 57,659 & \\
Sig & & 0,000 & \\
\hline *signifikan level 5\% & & & \\
$\quad * *$ signifikan level 10\% & & &
\end{tabular}

Hasil pengujian secara statistik menunjukan nilai signifikansi $F$ adalah 0,000 lebih kecil daripada 0,05 yang berarti bahwa secara serentak (bersama) seluruh variabel independen: transparansi, akuntabilitas, budaya hukum, partisipasi dan ukuran PEMDA 
(size, variabel kontrol) berpengaruh nyata terhadap kinerja keuangan daerah (variabel dependen). Koefisien determinasi menunjukan variabel independen dapat menjelaskan variabel dependen sebesar 85,3 persen, sedangkan 14,7 persen dijelaskan oleh variabel lain di luar model.

Hasil perhitungan statistik pada pengujian secara individual menunjukan bahwa variabel yang nilai signifikansinya lebih kecil dari alpha 0,05 (alternatif 0,10 ) adalah partisipasi $(0,000)$, Ukuran PEMDA $(0,000)$ dan budaya hukum $(0,100)$ yang berarti variabel-variabel tersebut secara individual berpengaruh nyata terhadap kinerja keuangan daerah. Pengaruh variabel transparansi $(0,494)$ dan akuntabilitas $(0,951)$ tidak nyata terhadap kinerja keuangan daerah, karena nilai signifikansinya lebih besar dari alpha 0,05 (alternatif 0,10).

Variabel transparansi (e-government) memiliki nilai koefisien regresi sebesar 0,099 yang artinya jika variabel ini naik sebesar satu satuan maka kinerja keuangan daerah akan naik sebesar 0,099. Hasil pengujian individual diketahui variabel transparansi (e-government) tidak berpengaruh terhadap kinerja keuangan daerah dengan nilai signifikansi $0,494(>0,05)$ sehingga hipotesis pertama ditolak. Hasil penelitian ini tidak mendukung temuan oleh Deakins et al. (2010) bahwa e-government berpengaruh pada peningkatan kinerja pemerintah daerah di China, New Zealand, Oman dan Inggris. Dalam konteks yang berbeda, temuan Patrick (2007) menunjukan bahwa e-government berpengaruh nyata terhadap inovasi organisasi berupa adopsi governmental accounting standard board (GASB) statement No 34. Beberapa penyabab bisa dikemukakan, antara lain: belum semua informasi disajikan dalam website, administratornya belum terlatih, konstruksi dan running website tidak dinamis, sarana akses yang kurang memadai dan sejenisnya. Hal tersebut yang mungkin membuat masyarakat tidak berminat mengakses website pemerintah daerah untuk keperluan-keperluan terkait, sehingga interaksi yang diharapkan menjadi tidak optimal.

Variabel akuntabilitas (opini audit BPK) memiliki nilai koefisien regresi sebesar 0,006 yang artinya jika variabel ini naik sebesar satu satuan maka kinerja keuangan daerah akan naik sebesar 0,006. Hasil pengujian individual diketahui variabel akuntabilitas (opini audit BPK) tidak berpengaruh terhadap kinerja keuangan daerah dengan nilai signifikansi $0,951(>0,05)$ sehingga hipotesis kedua ditolak. Hasil penelitian ini tidak sejalan dengan Mustikarani dan Fitriasari (2012) yang membuktikan secara empiris bahwa temuan audit BPK berpengaruh negatif terhadap kinerja pemerintah daerah. Permasalahan dalam penyusunan laporan keuangan yang mengacu pada PP No 71 Tahun 2010 perlu ditindak lanjuti dengan serius, misal dengan melakukan edukasi kepada para staf keuangan di PEMDA. Hal ini ditunjukkan pada ikhtisar hasil pemeriksaan oleh BPK RI tahun 2014 (LKPD 2013) bahwa hanya 7 persen LKPD Kota yang mendapat opini wajar tanpa pengecualian.

Nilai koefisien regresi variabel budaya hukum (indeks persepsi korupsi) adalah 0,076 yang artinya jika variabel ini naik sebesar satu satuan maka kinerja keuangan 
daerah akan naik sebesar 0,076. Hasil pengujian individual diketahui pengaruh variabel budaya hukum (indeks persepsi korupsi) adalah nyata dan menunjukan arah positif terhadap kinerja keuangan daerah dengan nilai signifikansi 0,100 (alpha 0,10), sehingga hipotesis ketiga (H3) dalam penelitian ini diterima. Hal ini berarti pemerintahan daerah yang bersih akan dapat meningkatkan kinerja keuangan daerah dan pemerintahan daerah yang korup akan menurunkan kinerja keuangan daerah. Hasil penelitian ini sejalan dengan Hasthoro (2014) dan Picur dan Riahi-Belkaoui (2006) yang membuktikan bahwa pengendalian terhadap korupsi pada 30 negara maju dan negara berkembang dapat meningkatkan kepatuhan pajak yang berdampak pada peningkatan pendapatan dan pembangunan ekonomi. Tingkat korupsi yang tinggi juga berhubungan dengan rendahnya pendapatan pemerintah (Tanzi \& Davoodi 1997).

Variabel partisipasi dalam penelitian ini mempunyai nilai koefisien regresi 0,473 yang artinya jika variabel ini naik sebesar satu satuan maka kinerja keuangan daerah akan naik sebesar 0,473. Hasil pengujian individual diketahui pengaruh variabel partisipasi adalah nyata dan menunjukan arah positif terhadap kinerja keuangan daerah dengan nilai signifikansi $0,000(<0,05)$, sehingga hipotesis keempat $(\mathrm{H} 3)$ dalam penelitian ini diterima. Hasil penelitian oleh Coryanata (2007) membuktikan partisipasi memperkuat hubungan pengetahuan anggota dewan dengan pengawasan keuangan oleh anggota dewan terhadap pemerintah daerah. Pengawasan yang meningkat oleh anggota dewan dapat memberi motivasi kepada pemerintah daerah untuk meningkatkan kinerjanya.

Ukuran pemerintah daerah (size) sebagai variabel kontrol dalam penelitian ini menunjukan pengaruh yang nyata terhadap kinerja pemerintah dengan nilai signifikansi 0,000. Hasil ini mengkonfirmasi temuan Sumarjo (2010), Mustikarani dan Fitriasari (2012) dan Hasthoro (2014) bahwa ukuran organisasi (size) merupakan prediktor penting dalam memengaruhi kinerja pemerintah daerah di Indonesia.

\section{SIMPULAN, KETERBATASAN DAN SARAN}

\section{Simpulan}

Penelitian ini dapat memberi bukti empiris bahwa budaya hukum dan partisipasi merupakan prediktor bagi kinerja keuangan pemerintah daerah, dengan ukuran organisasi (size) merupakan faktor penting sebagai variabel kontrol. Dalam pengujian regresi secara bersama-sama semua variabel independen mempunyai pengaruh terhadap variabel dependen. Penegakan hukum dan peningkatan partisipasi masyarakat perlu diupayakan lebih intensif oleh pemerintah daerah untuk memperoleh kepercayaan dan dukungan oleh masyarakat sehingga dapat meningkatkan kinerja.

\section{Keterbatasan dan Saran}

Ada beberapa keterbatasan dalam penelitian ini, yaitu pertama, data yang terkumpul hanya sedikit $(\mathrm{N}=50)$ karena keterbatasan sumber yang sesuai dengan topik (public governance) dan variabel penelitian sehingga hasil penelitian tidak bisa 
digeneralisir. Kedua, referensi penelitian sebelumnya dengan topik yang sama sulit untuk didapatkan sehingga tidak bisa membahas secara detail mengenai bukti empiris yang ada di Indonesia.

Penelitian selanjutnya diharapkan dapat mengatasi keterbatasan dalam penelitian ini. Penggunaan proksi untuk variabel public governance (transparansi, akuntabilitas, budaya hukum dan partisipasi) bisa dikembangkan lebih variatif dari yang digunakan dalam penelitian ini, misalkan dengan metoda survei menggunakan kuisioner.

\section{Implikasi}

Implikasi dari penelitian ini adalah public governance perlu diupayakan dengan lebih baik lagi. Proses demokratisasi dan pencapaian tujuan nasional harus diikuti dengan pengelolaan pemerintahan secara baik dan sungguh-sungguh di daerah. Penegakan hukum yang tanpa pandang bulu dan konsisten, terutama dalam pemberantasan korupsi harus menjadi prioritas dan niat bagi pemimpin daerah dan para stakeholder. Partisipasi masyarakat dalam proses demokratisasi (pemilihan umum) juga perlu ditingkatkan agar rakyat mempunyai kontrol yang kuat terhadap legislatif maupun eksekutif. Dukungan dan kepercayaan masyarakat yang tinggi diharapkan akan memacu motivasi pemerintah agar bekerja sebaik-baiknya dalam pencapaian kinerja.

\section{DAFTAR PUSTAKA}

Adhikari, Pawan, dan Frode Mellemvik. 2011. "The rise and fall of accruals: a case of Nepalese central government." Journal of Accounting in Emerging Economies 1 (2): 123-43. https://doi.org/10.1108/20421161111138495.

Akbar, Rusdi, Robyn Pilcher, dan Brian Perrin. 2012. "Performance measurement in Indonesia: the case of local government." Pacific Accounting Review 24 (3): 26291. https://doi.org/10.1108/01140581211283878.

Azhar, Muhammad Karya Satya. 2010. “Analisis kinerja keuangan pemerintah daerah kabupaten/kota sebelum dan setelah otonomi daerah.” Jurnal Keuangan \& Bisnis Program Studi Magister Manajemen Sekolah Tinggi Ilmu Ekonomi Harapan 2 (1): 57-70.

Bastian, Indra. 2010. Akuntansi sektor publik: Suatu pengantar. 3ed. Jakarta: Penerbit Erlangga.

Bertot, John Carlo, Paul T. Jaeger, dan Justin M. Grimes. 2012. "Promoting transparency and accountability through ICTs, social media, and collaborative e-government." Transforming Government: People, Process and Policy 6 (1): 78-91. https://doi.org/10.1108/17506161211214831.

Bovaird, Tony, dan Elke Löffler. 2003. Understanding public management and governance. London, UK: Routledge.

Coryanata, Isma. 2007. “Akuntabilitas, partisipasi masyarakat, dan transparansi 
kebijakan publik sebagai pemoderating hubungan pengetahuan dewan tentang Anggaran dan Pengawasan Keuangan Daerah (APBD)." In Simposium Nasional Akuntansi X Unhas Makasar.

Deakins, Eric, Stuart Dillon, Hamed al Namani, dan Chao Zhang (Kevin). 2010. "Local e-government impact in China, New Zealand, Oman, and the United Kingdom." International Journal of Public Sector Management 23 (6): 520-34. https://doi.org/10.1108/09513551011069004.

Forbes, Melissa, Carolyn J. Hill, dan Laurence E. Lynn, Jr. 2006. Public management and government performance: An international review. Cambridge: Cambridge University Press.

Hariyadi, B. 2002. "Pengaruh kebijakan fiscal stress terhadap kinerja keuangan pemerintah kabupaten/kota dalam menghadapi pelaksanaan otonomi daerah (Suatu kajian empiris di Propinsi Jawa Timur).” Pusat Data Ekonomi \& Bisnis 5.

Hasthoro, H. A. 2014. "Pengaruh karakteristik pemerintah daerah dan indeks persepsi korupsi terhadap kinerja keuangan daerah di Indonesia." Universitas Sebelas Maret Surakarta.

Hill, Carolyn J., dan Laurence E. Lynn. 2004. "Governance and Public Management, an Introduction." Journal of Policy Analysis and Management 23 (1): 3-11. https://doi.org/10.1002/pam.10175.

Komite Nasional Kebijakan Governance. 2010. "Pedoman Umum Good Public Governance."

Malagueño, Ricardo, Chad Albrecht, Christopher Ainge, dan Nate Stephens. 2010. "Accounting and corruption: a cross-country analysis." Journal of Money $\begin{array}{lllll}\text { Laundering } & \text { Control } & 13 & \text { (4): }\end{array}$ https://doi.org/10.1108/13685201011083885.

Mardiasmo. 2009. Akuntansi Sektor Publik. 7ed. Yogyakarta: Penerbit Andi.

Marwata, dan Manzurul Alam. 2006. "The interaction amongst reform drivers in governmental accounting changes: The case of Indonesian local government." Journal of Accounting \& Organizational Change 2 (2): 144-63. https://doi.org/10.1108/18325910610675989.

Mimba, Ni Putu S.H., G. Jan Van Helden, dan Sandra Tillema. 2007. "Public sector performance measurement in developing countries: A literature review and research agenda." Journal of Accounting \& Organizational Change 3 (3): 192208. https://doi.org/10.1108/18325910710820265.

Mistry, Jamshed J. 2012. "The role of egovernance in mitigating corruption." Accounting and the Public Interest 12 (1): 137-59. https://doi.org/10.2308/apin-10287.

Mustikarani, W. A., dan D. Fitriasari. 2012. "Pengaruh karakteristik pemerintah daerah 
dan temuan audit BPK terhadap kinerja pemerintah daerah kabupaten/kota di Indonesia tahun anggaran 2007." Proceeding Simposium Nasional Akuntansi XV Banjarmasin.

Osborne, Stephen P. 2010. "Introduction - The (new) public governance: A suitable case for treatment?" In The New Public Governance? Emerging perspectives on the theory and practice of public governance, 1-16. London, UK: Routledge. https://doi.org/10.4324/9780203861684.

Patrick, Patricia A. 2007. "The determinants of organizational innovativeness: The adoption of GASB 34 in Pennsylvania Local Government." The Graduate School of Public Affairs The Pennsylvania State University.

Picur, Ronald D., dan Ahmed Riahi-Belkaoui. 2006. "The impact of bureaucracy, corruption and tax compliance." Review of Accounting and Finance 5 (2): 17480. https://doi.org/10.1108/14757700610668985.

Sadjiarto, Arja. 2000. “Akuntabilitas dan pengukuran kinerja pemerintahan.” Jurnal Akuntansi dan Keuangan 2 (2): 138-50.

Sumarjo, H. 2010. "Pengaruh karakteristik pemerintah daerah terhadap kinerja keuangan pemerintah daerah (Studi empiris pada Pemerintah Daerah Kabupaten/Kota di Indonesia).” Program Studi Akuntansi Fakultas Ekonomi Universitas Sebelas Maret.

Tanzi, V., dan H. Davoodi. 1997. "Corruption, Public Investment and Growth.” 139. IMF Working Papper. https://doi.org/10.1007/978-4-431-67939-4_4.

Verbeeten, Frank H.M. 2008. "Performance management practices in public sector organizations Impact on performance." Accounting, Auditing \& Accountability Journal 21 (3): 427-54. https://doi.org/DOI 10.1108/09513570810863996.

Wyk, H A van. 2007. "Is the transformation of public sector financial reporting in South Africa's provincial governments on track?" Meditari Accountancy Research 15 (2): 65-75. https://doi.org/http://dx.doi.org/10.1108/10222529200700011. 